\title{
THE EFFECT OF TAX PLANNING AND DEFERRED TAX LIABILITIES ON EARN MANAGEMENT
}

\author{
Zulfa Rosharlianti*), Rahmat Hidayat \\ Universitas Pamulang \\ rosharlianti@gmail.com
}

\begin{abstract}
This researched are intended to analyze the effect of planning tax and deferred tax liabilities on earn management. Manufacturing companies listing on the IDX from 2013 to 2017 are the object of research. This research uses secondary data on annual reports obtained through the sites www.idx.co.id. Purposive sampling is the method used in sampling, with population of 132 entity and the sample in this research are 10 entities the observation period of 5 years, with the result that obtained 50 samples. The method data analisys of this researh used multiple regression analys with the SPSS version 24. The results shows that the tax planning has a negative effect on earn management, neither the deferred tax liabilities does not have effect on earn management. Simultaneously the tax planning and deferred tax liabilities have a positive effect on earn management.
\end{abstract}

Keywords: Deferred Tax Liabilities, Tax Planning, Earn Management.

\section{INTRODUCTION}

Profit is one of the main objectives of the establishment of the company. Profits obtained by the company when running its activities will be used for various purposes, such as being used to improves the welfare of the firm and preserve the sustainability of the firm. The profit level indicator can be obtained by taking into account two factors, namely income and costs.

Profit is an element that is the main focus of the financial statements presented by a company. The profit figures presented in the financial statements are expected to present how the performance of a company. Both the external and internal parties of the company will make profits as the basis for making various decisions such as providing compensation, investment and determining the amount of tax to be charged. So the quality of earnings is the center of attention for owners, investors, creditors, and the government (Directorate General of Taxes).

The company will be faced with intense competition to be able to exist and survive in facing global markets, especially for industries in Indonesia. There are 3 main industrial sectors in Indonesia, namely the manufacturing industry, the non-oil industry and the coal and oil and gas refining industries. These industrial sectors are the dominant contributors to the contribution of economic growth in Indonesia. Economic growth can be seen from Gross Domestic Product. Graph of GDP growth during 2010-2017 can be seen from the following picture: 


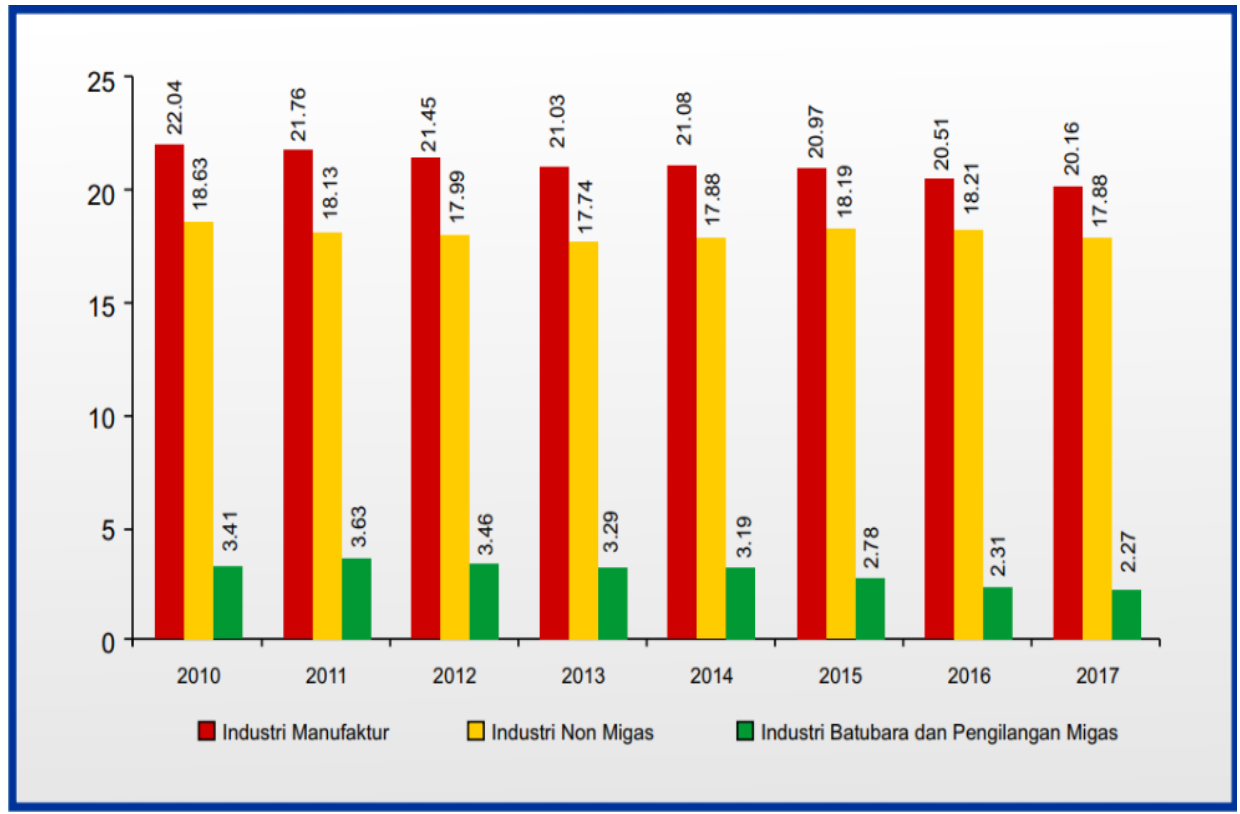

Figure 1: GDP of the Industrial Sector for the year 2010-2017

Source : http://www.kemenperin.go.id

Based on Figure 1.1, there is one industry sector that dominates the most compared to other sectors, namely the manufacturing sector, where GDP from 2010 to 2017 is more than $20 \%$. This is because the number of companies in the manufacturing industry is more than the non-oil and gas industry sector and the coal industry and oil and gas management.

In this era of globalization, companies are not only asked to produce quality products for consumers, but also must be able to manage their finances well so they can have competitive advantages from other companies. In a situation like this usually encourages managers to commit deviant behavior in presenting earnings information presented in financial statements known as earns management.

Earnings or profit management is any effort made by management in making decisions to intervene in processing, compiling and presenting profits in financial reports with the purpose of benefiting themselves or the firm. Earnings management can be explained using the practice of income smoothing, taking a bath, income minimization, income maximization, and Timing Revenue and Expenses Recognation (Scoot, 2000).

There are two versions of financial statements calculated by the company each year, namely commercial financial statements based on general accepted accounting principles and fiscal financial statements calculated based on applicable tax provisions.

Commercial profit difference and fiscal profit in the form of positive and negative corrections. (Djamaluddin, 2008: 58).

Deferred tax liability is the total of income tax owed for the coming period as a outcome of taxable temporary discrepancy, where commercial profit is greater than fiscal profit, which results in a commercial tax burden greater than the tax burden according to fiscal.

The management wants to suppress and make the tax burden as small as possible, then management tends to do tax planning that is by minimizing the tax burden. Generally tax planning is done by engineering the business and payment transactions so that the tax debt 
is at a minimum amount but does not violate applicable tax regulations, so tax planning is a legal action during the corridor of the applicable tax laws in Indonesia.

\section{LITERATURE REVIEW}

For literature pertaining to this study, the authors use Agency Theory and Signalling Theory. Jensen and Meckling (1976) agency theory is a theory that describes the agency conflict that occurs between two parties, namely the agent and the principal due to differences in interests between the two. In this research, the contravention that come about is between management who acts as an agent and the government acts as principal. The principal wants to impose as much tax as possible from management in accordance with applicable legal provisions, while the agent who acts as the party making the payment certainly wants to pay the refined tax possible to meet the needs and sustain the firm.

Signal clarify why the firm have the impulse to serve monetary statement information to external sides. Giving signals to outside parties is one way for companies to minimize information asymmetry, one way is to provide accountable financial information so that it will minimize uncertainty about future company prospects.

\subsection{Earn Management Definition, Types and approach}

According to Healy and Wahlen (1999) in Welvin I Guna and Arleen Herawaty (2013) earnings management is management of decision making by managers in financial reporting and processing all company transactions. This aims to facilitate interested parties who wants to know the financial performance of the firm and as a consideration of work contracts by paying attention to the numbers on the published financial statements.

\subsubsection{Earn Management by Tax Planning Approach}

Tax planning is part of tax management, where the purpose of planning this tax is to achieve minimum tax obligations. Tax planning is a structured action, which is related to transactions that intersect with tax regulations with the aim of streamlining the amount of tax to be transferred to the government (Zain, 2006).

Several other researchers conducted by Han Ayunda Amalia (2016) and Rici Noviyanti (2017) prove that tax planning has an influence on earn management.

$\mathrm{H}_{1}$ : Tax planning has a significant effect on earns management.

\subsubsection{Earn Management by Deferred Tax Liabilities Approach}

Deferred tax liability is a condition where profit according to commercial accounting is greater than profit according to fiscal accounting which causes the expenditure of tax burden according to commercial greater than fiscal (negative fiscal correction).

Some other researchers conducted by Anggi Hasian Sidabutar (2017) and Ivan Bakti Suryanto (2018) prove that deferred tax liabilities have a significant influence to avoid losses.

$\mathrm{H}_{2}$ : Deferred tax liabilities have a significant effect on earnings management.

\subsubsection{Earn Management by Tax Planning and Deferred Tax Liabilities Approach}

Tax planning is the first action in conducting tax management (Suandy, 2008) in form of a process of organizing a taxpayer's business or a group of taxpayers so that tax debt, both income tax and other tax burdens in the minimum amount to earn a profit the maximum. One tax plan is to regulate 
how much profit is reported, so that it is included in the indication of the existence of earnings management practices.

$\mathrm{H}_{3}$ : Tax planning and deferred tax liabilities have an effect on earns management.

\section{RESEARCH METHOD}

Author uses the data in this study is Earn Management, from the year 20132017.

\subsection{Variables and Measurements}

The variables in this research consisted of independent variables and dependent variables. There are, namely:

Table 1: Scale of Data Measurements

\begin{tabular}{|c|c|c|c|}
\hline No & Variabel & Indicator & $\begin{array}{l}\text { Scale of Data } \\
\text { Measurement }\end{array}$ \\
\hline \begin{tabular}{|l|}
1 \\
\end{tabular} & $\begin{array}{l}\mathrm{X}_{1}=\text { Tax } \\
\text { Planning }\end{array}$ & $E T R=\frac{\text { Beban pajak }}{\text { Laba Sebelum Pajak }}$ & Ratio \\
\hline 2 & \begin{tabular}{|l|}
$\mathrm{X}_{2}=$ \\
Deferred \\
Tax \\
Liabilities
\end{tabular} & $\begin{array}{l}D_{\text {it }} \\
=\frac{\text { Kewajiban Pajak Tangguhan } t}{\text { Total Assest } t-1}\end{array}$ & Ratio \\
\hline 3 & $\begin{array}{l}\mathrm{Y}= \\
\text { Earn } \\
\text { Management }\end{array}$ & $\Delta E=\frac{E_{i t}-E_{i t}-1}{M V E_{t}-1}$ & Ratio \\
\hline
\end{tabular}

Source: Results of data processing by researchers

The process of selecting samples in this study is use the purposive sampling method. The criteria of the company which used as the sample of this study data are as takes: (1) Manufacturing companies listing on IDX in 2013-2017; (2) Companies that report audited financial statements from 2013 to 2017; (3) The company does not make acquisitions, mergers, restructuring and changes in business groups; (4) Companies that use rupiah; (5) The company's financial statements have complete information related to all the variables studied.

\subsection{Data Analysis Techniques}

For the analysis of the data used is the method of quantitative analysis. In this research, researchers using the SPSS application 24 version as a tool to test data.

\subsubsection{Descriptive Statistics}

Descriptive statistics are methods related to the aggregation and presentment of a data category so as to serve beneficial information. (Ronald E. Walpole)

\subsubsection{Test of Classical Assumptions}

Classical assumption testing is done to see the model being studied has a classic or not, so the examination of deviations from this classic assumption needs to be done.

\subsubsection{Analysis of Multiple Linear Regression}

This analysis is to decide the way of the connection between the dependent and independent variable if each independent variable is positively or negatively related. The hypothesis in this research was tested using multiple regression analys. While equation model used is: $\quad Y=a+b_{1} X_{1}+b_{2} X_{2}+e$

\subsubsection{Determination (R) Coefficient Test \\ $\mathrm{R}^{2}$ test or determination test is an} important measure in regression, because it can inform whether or not the estimated regression model, or in other words, it can measure how closely the regression line is estimated by the actual data.

\subsection{5. $t$ Test}

The $t$ test is proposed to know if the suggested hypothesis is accepted or rejected and also to test the significant level of the influence of the independent variable on the dependent variable. 


\subsubsection{F Test}

This test is used to verify the feasibility of the goodness of fit model, which is testing hypotheses to determine whether an expected set of frequencies is equal to the frequency obtained from a distribution (binomial, poisson, normal and so on). The significant level used is $5 \%$.

\section{RESULTS AND DISCUSSION}

From a population of 132 companies, it turns out that only 10 companies have complete data needed by researchers related to the research needs of all the variables studied. Analysis of the results of this research will be in the form of outlines in table 2 to table 9 :

\subsection{Research Result Analysis}

\subsubsection{Descriptive Statistics Test Results}

The outcomes of testing these variables descriptively can be seen in the succeeding table:

Table 2 : Descriptive Statistics Test Results

\begin{tabular}{|l|l|l|l|l|l|}
\hline & \multicolumn{1}{|c|}{$\mathrm{N}$} & \multicolumn{1}{|c|}{ Min } & \multicolumn{1}{c|}{ Max } & \multicolumn{1}{c|}{ Mean } & $\begin{array}{c}\text { Standard } \\
\text { Deviation }\end{array}$ \\
\hline Tax Planning & 50 &,- 1125 &, 5957 &, 246002 &, 0902696 \\
\hline \multicolumn{1}{|c|}{ Deferred Tax Liabilities } & 50 &, 0003 &, 0574 &, 014234 &, 0133675 \\
\hline Earn Management & 50 &,- 0458 &, 0809 &, 006134 &, 0244297 \\
\hline Valid N (listwise) & 50 & & & & \\
\hline
\end{tabular}

Source : Self Proceed

Tax planning is less than 1 or with an average of 0.246002 indicating that tax planning is done well.

Deferred tax liability with an average value of 0.014234 shows that the level of deferred tax liabilities incurred in manufacturing companies is relatively low.

Earnings management with an average value of 0.006134 indicates that earns management practice execute by manufacturing companies are fairly low.
This indicates good because of the lack of earns management practice execute by manufacturing companies.

\subsubsection{Classical Assumption Test Results}

The classic assumption test purposes to test the assumptions that are implied in multiple regression analysis to meet the criteria or not the research conducted.

Table 3 : Normality Test Results

One-Sample Kolmogorov-Smirnov Test

\begin{tabular}{|l|l|r|}
\hline \multicolumn{2}{|c|}{} & \multicolumn{1}{|c|}{ Unstandardized Residual } \\
\hline \multirow{2}{*}{$\mathrm{N}$} & Mean & 50 \\
\hline \multirow{2}{*}{ Normal Parameters } & a,b &, 0000000 \\
\cline { 2 - 3 } & Std. Deviation &, 02126392 \\
\hline \multirow{3}{*}{ Most Extreme Differences } & Absolute &, 120 \\
\cline { 2 - 3 } & Positive &, 120 \\
\cline { 2 - 3 } & Negative &,- 119 \\
\hline \multicolumn{2}{|l|}{ Test Statistic } &, 120 \\
\hline Asymp. Sig. (2-tailed) &, $070^{c}$ \\
\hline
\end{tabular}


Based on table 3, the results of the Kolmogrov Smirnov (K-S) test show that the data is normally distributed. This can be seen from the level of significance (Asymp. Sig. Value (2- tailed)) of 0.07 and the value above $\alpha=$ $5 \%$. This ways that the data is normally distributed, so the model of this study has met the test of the classical assumption of normality.

Table 4: Multicollinearity Test Results

\begin{tabular}{|c|c|c|}
\hline \multirow[b]{2}{*}{ Model } & \multicolumn{2}{|c|}{ Collinearity Statistics } \\
\hline & Tolerance & VIF \\
\hline (Constant) & & \\
\hline Tax Planning & 911 & 1,098 \\
\hline Deferred Tax Liabilities & 911 & 1,098 \\
\hline
\end{tabular}

a. Dependent Variable: earn management

Source : Self Proceed

Based on table 4, it can be concluded that the value of tolerance is 0.911 which means that the tolerance value is $>0.10$ and the VIF value is 1.098 , which means VIF $<10$, it can be concluded that the multicollinearity regression model can be used in this study.

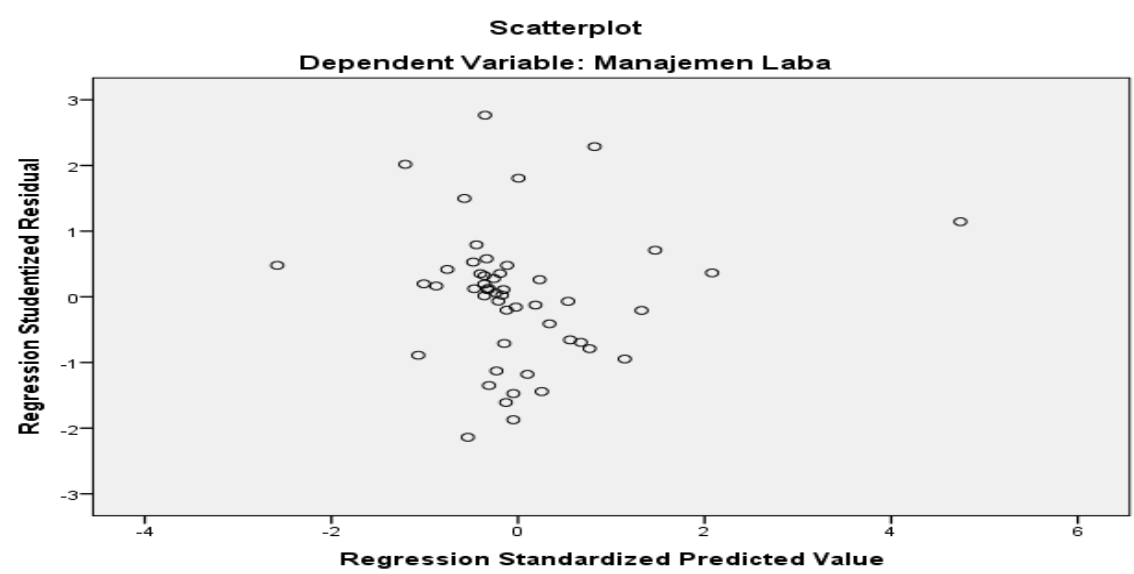

Figure 2 : Heteroscedasticity Test Results

From Figure 2 shows that the points are scattered with irregular patterns below and above 0 and $\mathrm{Y}$ axis, so it can be noted that there is no heterocedasticity in the regression model, so that regression models can be used in conducting research.

Table 5 : Autocorrelation Test Results

\begin{tabular}{|c|c|c|c|c|c|}
\hline Model & $\mathrm{R}$ & $\mathrm{R}$ Square & $\begin{array}{c}\text { Adjusted R } \\
\text { Square }\end{array}$ & $\begin{array}{c}\text { Std. Error of the } \\
\text { Estimate }\end{array}$ & Durbin-Watson \\
\hline 1 &, $492^{\mathrm{a}}$ &, 242 &, 210 &, 0217116 & 2,026 \\
\hline
\end{tabular}

Based on table 5 it can be visible that this grade of Durbin-Watson (DW) is 2.026. Then the grade is compared with a significant $5 \%$ table value, the number of samples $\mathrm{N}=50$ and the number of independent variables $2(K=2)$, then obtained a DL value of 1.4625 and DU of 1.6283. The DW value of 2.026 is superior than the DU limit which is equal to 1.6283 and less than 4-DU (41.6283 ) of 2.33717 , so it can be resumed that there is no autocorrelation. 


\subsubsection{Multiple Linear Regression Test Results}

This analys is to decide the way of the correlatioan between the dependent and independent variable.

Table 6: Multiple Linear Regression Test Results

\begin{tabular}{|l|l|r|r|}
\hline \multirow{2}{*}{ Model } & \multicolumn{3}{|c|}{ Unstandardized Coefficients } \\
\cline { 2 - 4 } & \multicolumn{2}{|c|}{ Std. Error } \\
\hline \multirow{2}{*}{ (Constant) } & \multicolumn{1}{|c|}{ B } &, 034 &, 009 \\
\cline { 2 - 4 } & Tax Planning &,- 138 &, 036 \\
\cline { 2 - 4 } & Deferred Tax Liabilities &, 401 &, 243 \\
\hline
\end{tabular}

Table 6 shows that the multiple regression equality is obtained the following:

Earn Management $=$

$0,034-0,138 \mathrm{X}_{1}+0,401 \mathrm{X}_{2}+\mathrm{e}$

1. Constants

When tax planning and deferred tax liabilities are in a constant or constant state, the amount of management earnings action is equal to 0.034 . Assuming other factors are considered zero.

3. Tax Planning

The tax planning regression coefficient is 0.138 and has a negative sign, this means that each change in one-time tax planning with the assumption of other variables remains the possibility of

Table 7 : Determination Coefficient Test Results

\begin{tabular}{|r|r|r|r|r|r|}
\hline Model & $\mathrm{R}$ & R Square & \multicolumn{1}{|l|}{$\begin{array}{l}\text { Adjusted R } \\
\text { Square }\end{array}$} & $\begin{array}{c}\text { Std. Error of } \\
\text { the Estimate }\end{array}$ & Sig. F Change \\
\hline 1 &, $492^{\mathrm{a}}$ &, 242 &, 210 &, 0217116 &, 001 \\
\hline
\end{tabular}

a. Predictors: (Constant), Kewajiban Pajak Tangguhan, Perencanaan Pajak

On table 7 shows that the coefficient of determination obtained is equal to 0.242 or $24.2 \%$. This ways that the effect of independent variables (deferred tax liabilities and tax planning) on the dependent variable (earns management) is $24.2 \%$. earnings management practices will decrease by 0.138 times.

4. Deferred Tax Obligations

The regression coefficient of deferred tax liability is 0.401 , this means that each change in deferred tax liability once with the assumption of other variables remains the likelihood of earns management practice will increase by 0.401 times.

\subsubsection{Determination Coefficient Test Results}

The test results of the coefficient of determination $\left(\mathrm{R}^{2}\right)$ can be seen from the table presented as follows:

\begin{tabular}{|c|c|c|c|c|c|}
\hline \multirow[b]{2}{*}{ Model } & \multicolumn{2}{|c|}{ Unstandardized Coefficients } & \multirow{2}{*}{$\begin{array}{c}\begin{array}{c}\text { Standardized } \\
\text { Coefficients }\end{array} \\
\text { Beta }\end{array}$} & \multirow[b]{2}{*}{$\mathrm{T}$} & \multirow[b]{2}{*}{ Sig. } \\
\hline & B & Std. Error & & & \\
\hline (Constant) &, 034 & ,009 & & 3,814 &, 000 \\
\hline Tax Planning &,- 138 & 036 &,- 511 & $-3,842$ & 000 \\
\hline Deferred Tax Liabilities & ,401 & 243 & 220 & 1,651 &, 105 \\
\hline
\end{tabular}


On table 8 the outcomes of the partial $\mathrm{t}$ test for tax planning variables obtained a significance value of 0,000 . Significance value is smaller than $\alpha=$ $5 \%$, or the value of $0.000<5 \%$ and the amount of tcount is 3.842 with $t$ table of $2.0117(\mathrm{df}=\mathrm{nk})$ or $3.842>2.0117, \mathrm{t}$ negative indicates that $\mathrm{X} 1$ has the opposite relationship direction with Y. So it can be resumed that tax planning has a significant negative effect on earns management.

Deferred tax liabilities obtained a significance amount of 0.105 , a significance amount greater than $\alpha=5 \%$ or a value of $0.105>0.05$ and a tcount of 1.651 with ttable 2.0117 (df = nk) or $1.651<2.0117$, positive $t$ value shows that X2 has a relationship with the $\mathrm{Y}$ direction. So it can be resumed that the deferred tax liability does not have an effect on earns management.

\subsubsection{Test F (Simultaneous)}

If the level of significance is greater than $5 \%$, the argued hypothesis is rejected or not significant (Ha is rejected and $\mathrm{H}_{0}$ is accepted), meaning that independent variables $\left(\mathrm{X}_{1}, \mathrm{X}_{2}\right)$ do not significantly influence the dependent variable $(\mathrm{y})=$ hypothesis rejected Table 9: Simultaneous Hypothesis Test Results (Test F)

\begin{tabular}{|c|c|c|c|c|c|c|}
\hline \multicolumn{2}{|c|}{ Model } & $\begin{array}{c}\text { Sum of } \\
\text { Squares }\end{array}$ & Df & $\begin{array}{c}\text { Mean } \\
\text { Square }\end{array}$ & F & Sig. \\
\hline & Regression &, 007 & 2 &, 004 & 7,518 &, $001^{\text {b }}$ \\
\cline { 2 - 7 } & Residual &, 022 & 47 &, 000 & & \\
\cline { 2 - 7 } & Total &, 029 & 49 & & & \\
\hline
\end{tabular}

Based on table 9 indicates that the significance amount is 0.001 . Significance value is smaller than $\alpha=$ 0.05 , or $0.001<0.05$ and the calculated $\mathrm{F}$ value is 7.518 and Ftable is $3.2\{(\mathrm{df}=$ $\mathrm{k}-1)(\mathrm{df} 2=\mathrm{n}-\mathrm{k})\}$ or $7.518>3.2$. Because $\mathrm{F}$ count $>\mathrm{F}$ table, it can be concluded that $\mathrm{H}_{3}$ (tax planning and deferred tax liabilities) has a significant positively impact simultaneously on earn management.

\section{CONCLUSION}

Based on the outcomes of tests organized by researchers, the research aimed at analyzing the impact of Tax Planning and Deferred Tax Obligations on Profit Management concluded:

1. Tax planning has a negative impact on earnings management, meaning that the higher the tax planning, the smaller the firm's chance to practice earns management. Conversely, the lower the tax planning, the greater the chance for companies to practice earnings management. Tax planning has a strong influence on earns management.

2. Deferred tax liabilities do not have a significant impact on earns management, meaning that the higher or lower deferred tax obligations will not impact the earns management practices of the firm.

3. Simultaneously deferred tax liabilities and tax planning has a significant positive influence on earnings management, meaning that the higher tax planning and deferred tax liabilities, the greater the chance for companies to practice earnings management. On the contrary, the lower the tax planning and deferred tax liabilities, the smaller the opportunity for companies to practice earnings management. Tax planning and deferred tax liabilities have a strong influence on earnings management simultaneously. 


\section{REFERENCES}

Arles, P. Ompusunggu. (2011) Cara Legal Siasati Pajak. Jakarta: Puspa Swara.

Erly Suandi. (2002). Perencanaan Pajak. Jakarta: Salemba Empat.

Erly, Suandi. (2006). Perencanaan Pajak. Jakarta: Salemba Empat.

Erly Suandi. (2008). Perencanaan Pajak. Jakarta: Salemba Empat.

Han, Ayunda Amalia. (2016). Pengaruh Perencanaan Pajak Terhadap Manajemen Laba. Universitas Pamulang Tangerang.

Harnanto. (2003). Akuntansi Perpajakan. Yogyakarta: BPFE.

Hidayat, A. (2017). Konsep Diri Dan Kecemasan Mahasiswa Dalam Pemecahan Masalah Matematika Bisnis Ditinjau Dari Perbedaan Gaya Kognitif Field Dependent Dan Field Independent. Gammath: Jurnal Ilmiah Program Studi Pendidikan Matematika, 2(1).

Hidayat, A., \& Yuliah, N. (2018). The Effect of Good Corporate Governance and Tax planning on Company Value. EAJ (Economics and Accounting Journal), 1(3), 234-241.

Jensen, M. and Meckling W. (1976). Theory of The Firm: Managerial Behavior, Agency Cost and Ownership Structure. Jurnal of Financial Economics Vol.3 No.4 Hal. 305-360.

Langen, W.J. de. (1954). De Grondbeginselen Van Het Ned. Belastingrecht Jilid I.

Mardiasmo. (2011). Perpajakan. Yogyakarta: Andi.

Mohamad Zain. (2005). Manajemen Perpajakan. Jakarta: Salemba Empat.

R. Santoso Brotodiharjo. (2010). Pengantar Ilmu Hukum Pajak. Bandung: Refika Aditama.
Rici Noviayanti. (2017). Pengaruh Perencanaan Pajak dan Kewajiban Pajak Tangguhan Bersih Terhadap Manajemen Laba. Universitas Pamulang Tangerang.

Rochmat Soemitro. (2002). Teori Perpajakan dan Kasus. Jakarta: Salemba Empat.

Scott, William R. (2003). Financial Accounting Theory-Third Edition. New Jersey: Prentice Hall Internasional Inc.

Sidabutar, Anggi Hasian. (2017). "Pengaruh Aktiva Pajak Tangguhan dan Kewajiban Pajak Tangguhan Terhadap Manajemen Laba". Universitas Pamulang Tangerang.

Siti Resmi. (2007). Perpajakan Teori dan Kasus. Jakarta: Salemba Empat.

Smith, Adam. (1981). An Inquiry Into The Nature and Causes of The Wealth of Nations. Indianapolis: Liberty Classics.

Sugiyono. (2012). Metode Penelitian Bisnis (Pendekatan Kuantitatif, Kualitatif dan $R \& D)$ ). Bandung: Afabeta.

Undang-Undang No. 28 Tahun 2007 tentang "Ketentuan Umum dan Tata Cara_Perpajakan" pasal 1.

Waluyo. (2008). Perpajakan Indonesia. Jakarta: Salemba Empat.

Waluyo. (2012). Perpajakan di Indonesia Pembahasan Sesuai Dengan Ketentuan Pelaksanaan Perundang-undangan Perpajakan. Jakarta: Salemba Empat.

Welvin I. Guna dan Arleen Herawaty. (2010). Pengaruh Mekanisme Good Coorporate Governance, Independensi Auditor, Kualitas Audit dan Faktor Lainnya Terhadap Manajemen Laba. Jurnal Bisnis dan Akuntansi Vol. 12 No. 1 Hal. 53-68. 